\title{
Mortality among patients with idiopathic intracranial hypertension enrolled in the IH Registry
}

Neurology ${ }^{\circledR}$ 2020;95:325. doi:10.1212/WNL.0000000000010352

In the final published version of the article "Mortality among patients with idiopathic intracranial hypertension enrolled in the IH Registry" (previously available as a post-acceptance publication ahead of print) by Hermes et al., the addendum "These findings should be interpreted with caution as the IHR database is likely subject to selection bias" was included as the last sentence in the Conclusions section of the Abstract, to clarify the interpretation of the conclusions noted, and to ensure the Abstract accurately reflects the authors' conclusions as they are stated in the Discussion section of the article itself. The editors regret the omission of this sentence from the previous version of the article.

\section{Reference}

1. Hermes SM, Miller NR, Waslo CS, et al. Mortality among patients with idiopathic intracranial hypertension enrolled in the IH Registry. Neurology 2020;95:e921-e929.

\section{Teaching NeuroImages: CNS pituitary-hypothalamic Langerhans cell histiocytosis in an adult}

Neurology ${ }^{\circledR}$ 2020;95:325. doi:10.1212/WNL.0000000000010320

In the Teaching NeuroImages article "Teaching NeuroImages: CNS pituitary-hypothalamic Langerhans cell histiocytosis in an adult" by Yeaney et al., ${ }^{1}$ published online January 13, 2020, and in print January 28, 2020, the reference to figure 1 should appear following this sentence: "MRI showed a $1.7-\mathrm{cm}$ enhancing mass involving the infundibulum and hypothalamus." The authors regret the error.

\section{Reference}

1. Yeaney GA, Kshettry VR, Isada C. Teaching NeuroImages: CNS pituitary-hypothalamic Langerhans cell histiocytosis in an adult. Neurology 2020;94:e434-e435.

\section{Clinical Reasoning: A 45-year-old man with progressive insomnia and psychiatric and motor symptoms \\ Neurology ${ }^{\circledR}$ 2020;95:325. doi:10.1212/WNL.0000000000010179}

In the Resident \& Fellow paper "Clinical Reasoning: A 45-year-old man with progressive insomnia and psychiatric and motor symptoms" by Lima et al., there is an error in the fifth paragraph of section 2 of the paper-the second sentence in this paragraph should read "The immunoglobulin $\mathrm{G}$ index was not elevated $(0.5)$ and no oligoclonal bands were observed in the CSF or serum." The authors regret the error.

\section{Reference}

1. Lima J, Youn T, Robinson C, et al. Clinical Reasoning: A 45-year-old man with progressive insomnia and psychiatric and motor symptoms. Neurology 2020;94:e1213-e1218. 


\section{Neurology}

\section{Clinical Reasoning: A 45-year-old man with progressive insomnia and psychiatric and motor symptoms}

Neurology 2020;95;325 Published Online before print July 1, 2020

DOI 10.1212/WNL.0000000000010179

\section{This information is current as of July 1, 2020}

Updated Information \& Services

References

Permissions \& Licensing

Reprints including high resolution figures, can be found at: http://n.neurology.org/content/95/7/325.3.full

This article cites 1 articles, 1 of which you can access for free at: http://n.neurology.org/content/95/7/325.3.full\#ref-list-1

Information about reproducing this article in parts (figures,tables) or in its entirety can be found online at:

http://www.neurology.org/about/about_the_journal\#permissions

Information about ordering reprints can be found online:

http://n.neurology.org/subscribers/advertise

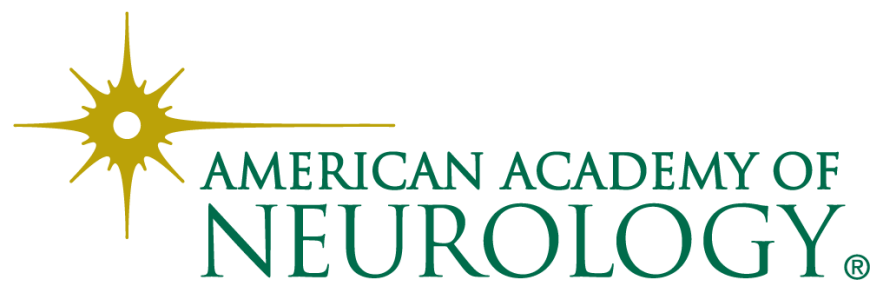

